\title{
Are heated tobacco products a healthy alternative to cigarettes?
}

\section{Anna Romaszko-Wojtowicz, Anna Doboszyńska}

Pulmonology Clinic, Collegium Medicum, University of Warmia and Mazury in Olsztyn

\section{Correspondence:}

Anna Doboszyńska

Pulmonology Clinic, Collegium Medicum, University of Warmia and Mazury in Olsztyn

10-357 Olsztyn, Jagiellońska 78 e-mail:anna.doboszynska@wp.pl

Received: 1.02.2021 Accepted: 31.03.2021

DOI: 10.24292/01.OR.121310321 Copyright $\odot$ Medical Education. All rights reserved.

\section{ABSTRACT}

As well as being an extremely widespread addiction, tobacco smoking is a well-known cause of numerous deaths around the world. Most (80-90\%) of lung cancer cases occur among smokers. The awareness of harmful effects of smoking is growing constantly. Manufacturers of tobacco products have recently opted to face this challenge by marketing heated tobacco products. Based on the performed research, tobacco companies maintain that these products are less harmful. They advertise their products as a smokeless, unconventional, less harmful cigarette. Due to the short follow-up period, the studies on consequences of using heated tobacco products are still scarce. This article presents a review of the literature focused on the use of heated tobacco products as an alternative to traditional cigarettes.

Key words: heated tobacco products, cigarettes, IQOS, smoking, alternative 


\section{INTRODUCTION}

Tobacco products, especially traditional cigarettes, are epidemiologically linked to a considerable increase in the risk of development of many illnesses, including a lung cancer. Owing to the widespread implementation of numerous prevention programmes, the awareness of the harmfulness of tobacco smoking is growing constantly among the public. The number of tobacco smokers has been on the decrease since the early 1960s [1]. However, there is a substantial number of people who - despite pharmacological and psychotherapeutic support, or merely the knowledge of the risk - cannot or do not want to quit smoking. Producers of heated tobacco products (HTPs) claim that levels of toxins and other dangerous compounds in these products are considerably lower, and inhalation of the modified aerosol is less harmful [2,3]. HTPs are a hybrid of a conventional cigarette and an e-cigarette. Is then the use of heated tobacco products a safer alternative to cigarettes?

One of the most popular devices for heating tobacco is the IQOS (I-QUIT-ORDINARY-SMOKING) system, developed by Philip Morris International (PMI). This company has a $15.5 \%$ share in the global tobacco market outside the USA, and its major brands of cigarettes are the well-known Marlboro or L\&M, sold all over the world [4]. Based on the in-company research, Philip Morris International has concluded that tobacco heating is less harmful than smoking [5-8]. HTPs are less common than traditional and e-cigarettes, but a growing interest in these products is observed nowadays.

The demand for tobacco products is so huge that the economic cost of tobacco smoking globally reached nearly 2 trillion US dollars in 2016, thus making up almost $2 \%$ of global economic output. In Poland alone, the state budget's revenue from selling tobacco products in 2019 was 28.7 billion Polish zloty [9]. According to the 2015 data published by the American Cancer Society (ATC), 942 million men and 175 million women above 15 years of age smoke tobacco products globally [10]. In 2019, Borland et al. carried out a cohort study where it was estimated that an average smoker would have made around 40 attempts to quit smoking by the age of 40 [11]. It is also assessed that chances to quit smoking unassisted are less than $5 \%$.

The purpose of this article is to review the literature concerning tobacco products, especially the use of heated tobacco products as an alternative to conventional cigarettes.

\section{CONSEQUENCES OF TOBACCO SMOKING}

Addiction to tobacco is linked to numerous premature deaths, which may have been prevented. Fatal cases are due to many neoplastic diseases, so-called tobacco-dependent cancers (e.g. cancers of lungs, larynx, pharynx, oesophagus or urinary tract), referred to as the $21^{\text {st }}$ century epidemic $[12,13]$. Furthermore, tobacco smoking certainly contributes to the development of pulmonary diseases, coronary disease, stroke, critical limb ischemia, and many other illnesses, leading to the death of over half of the population who regularly consume tobacco $[14,15]$. It has been demonstrated that tobacco smoking shortens the life span by about 10 years; for comparison, the estimated loss in longevity due to hypertension is 1 to 3 years $[16,17]$. Although most smokers are aware that smoking is bad for their health, this addiction remains the major cause of premature deaths around the world. According to the 2017 data published by the Global Burden of Disease Study, there are 8.1 million fatalities around the world each year due to tobacco consumption, including: 7.1 million caused by tobacco smoking, 76,000 due to tobacco chewing and 1.22 million because of second-hand tobacco smoking [18].

Since the mid-1980s, lung cancer has been the most frequently diagnosed cancer in the world (excluding the cancer originating from keratinocytes), and the major cause of cancer-related death. Lung cancer corresponds to $17 \%$ and $9 \%$ of all cancers among men and women, respectively, and is responsible for $19 \%$ of all deaths due to cancer [19]. In Poland, 140,500 persons, including around 70,000 men and 70,500 women, are diagnosed with cancer every year. Compared to other European Union countries, the morbidity of malignant cancers in Poland is lower: $20 \%$ among men and around $10 \%$ among women [20-22].

Because of the changing trends in the population growth, ageing of the society, and the burden of accompanying illnesses and environmental factors, it is necessary to constantly monitor the global epidemiology of lung cancer. According to the Human Development Index (HDI), which is a measure of the social development of a state, the countries classified as 'average' and 'low' record nearly half $(49 \%)$ of all cases of lung cancer in the world $[23,24]$.

As heated tobacco products were first launched in 2014, there has been little time for observations and therefore there are no studies concerning the long-term consequences of using this type of tobacco. Thus, it is extremely difficult to conclude whether they have a negative or a positive influence, for example in terms of the incidence of neoplastic diseases. It is practically im- 
possible to assess the risk of development of lung cancer due to HTPs. Likewise, making any comparison of distant consequences of heated tobacco use is prevented by the short period of exposure to these products.

At present, it is impossible to assess unequivocally the risk of the development of lung cancer due to HTPs. Comparison of distant consequences of inhaling heated tobacco is not possible due to the short period of exposure. In 1975, Calms noted that the average time that elapses from exposure to tobacco to development of lung cancer is 20 years [25]. The same conclusion was drawn by Islami et al. in 2015 [26]. Slightly divergent results, because of a different structure of their research, were published by Tindle et al. in 2018. These authors divided the population into active smokers, smokers who had quit smoking, and people who had never smoked. They proved that lung cancer developed on average after 5 years in so-called heavy smokers, after 15 years in those who had stopped smoking and after 25 years in those who had never been smoking [27]. HTPs have been popular for just a few years. Another research obstacle is the fact that IQOS are most often chosen by people who have already been smoking and therefore at a potentially higher risk of developing lung cancer. However, based on biological models and current knowledge about cancers, it is believed that there is still a high risk to life posed by using such novel tobacco products [28]. There are already some indications in the available literature suggesting that HTPs are harmful. Lee et al. conducted a cross-sectional study on 58336 Korean students, and demonstrated that the use of various tobacco products, including HTPs, may contribute to an increased risk of asthma, allergic rhinitis and atopic dermatitis [29]. The use of IQOS (a type of HTPs) may also cause toxic damage to the liver, which is unobserved in people smoking traditional cigarettes [30].

\section{HEATED TOBACCO PRODUCTS - THE HISTORY AND THE NEW REALITY}

The HTP technology is not new. As mentioned previously, its earliest form appeared in the 1960s, when these products were called 'a healthier cigarette' [31]. However, it was not until the 1980s that this system was first used by tobacco companies. In 1988, the American company RJ Reynolds (RJR) began the marketing of the first HTP Premier. The company's aim was to produce a cigarette that would offer the pleasure and satisfaction of smoking but would not be burdened with so many negative consequences as the conventional cigarette [32]. However, none of the products they sold was successful enough. The technology was not advanced enough to enable the manufacture of adequate batteries, a hurdle also encountered during the development of mobile telecommunication. A new stage in the launching of these products began in 2014, and was associated with such marketing slogans as 'an unconventional cigarette', 'smokeless', or 'reducing damage' [33, 34]. In 2018, HTPs became available in many countries across the world [35].

In a regular cigarette, while tobacco smoke is being inhaled into the lungs, tobacco burns at a temperature of $700-900^{\circ} \mathrm{C}$. The process of combustion, however, occurs only at the tip of a smoked cigarette. One phase of the thermal tobacco burning process includes pyrolysis, which results in the generation of most of the toxic smoke ingredients. A decrease in the incineration temperature became one of the methods to reduce the exposure to harmful substances [36]. Owing to the novel technology applied in HTP devices, an electric source of heat warms up tobacco to $350^{\circ} \mathrm{C}$, which is enough to release nicotine-containing, aromatic vapour [35, 37, 38]. Studies commissioned by tobacco companies show that the aerosol produced by heating tobacco products contains lower levels of toxic substances than tobacco smoke does [39]. In e-cigarettes, the user inhales aerosol produced by heating liquid nicotine.

However, a systematic review issued in 2018 demonstrated that most of the published research was closely linked to the tobacco industry (20 out of 31 studies) [40]. It turned out that the studies conducted by tobacco companies are in vitro or in vivo experiments, while clinical studies on human populations are practically non-existent [41-43]. It is therefore essential to verify the data published by tobacco companies which indicate that HTPs are less harmful.

\section{THE HAZARDOUS PHENOMENON OF TOBACCO HEATING PRODUCTS}

The data published by the US Department of Health and Social Care show that young people are the prevalent group of consumers of e-cigarettes [44]. According to the 2020 data, $19.6 \%$ of higher school students use e-cigarettes, while $1.4 \%$ opt for HTPs [45]. $20 \%$ of adolescents use several types of tobacco products [46]. Such behaviour is associated with a greater inclination to reach for heated tobacco products. Younger people, being more engaged in social media, are more likely to be influenced by advertising. The company Philip Morris International (PMI), which launched IQOS with the help of various marketing techniques, appeals to young people by advertising their product as 'an essentially different tobacco product' or 'a smokeless alternative to cigarettes' [47]. It is estimated that in the year 2018 alone tobac- 
co companies spent around 9.06 billion US dollars on marketing their products in the USA [48].

Consumer culture, fostered by aggressive advertising, favours the use of such products as IQOS. A study completed by Kim et al. dealing with the use of conventional and heated tobacco products showed that some part of the general public associated the use of HTPs with wealthy people (the cost of using these devices is higher than that of smoking regular cigarettes) or people searching for new experiences [49]. What matters here is the marketing strategy of companies manufacturing HTDs, which promote free-of-charge or inexpensive training sessions in shops or offer starter packages at discount prices [50]. The fashionable looks of an IQOS device, which resembles a pen and draws on the cutting-edge technologies, induces young people to reach for this product. Cheol Min Lee in a paper published in 2020 proved that most HTP users were young, well-educated and high-income people [51].

The popularity of IQOS products continues to grow. For example, less than 1\% of the population in Japan used this product in 2015 but this figure rose to $3.6 \%$ in 2017 [52]. A study completed by Hair et al. demonstrated that such assets as cleanliness (no smell of tobacco smoke) contribute to the greater appeal of the IQOS system [53].

In 2014, the European Parliament passed the tobacco directive, which prohibits the sale of cigarettes with a characterising flavour, including menthol cigarettes. This directive came into force on May $20^{\text {th }}, 2020$ [54]. Numerous studies on adolescents and young adults have shown, however, that preferences for specific flavours still play an important role in consumer choices [55-57] Based on data concerning e-cigarettes, it has been proven that 8 out of 10 e-cigarette users choose flavoured liquids [45]. The HTP products also contain a flavouring agent, which is so highly appreciated among young smokers.

\section{HTP - "A HEALTHY ALTERNATIVE"}

The idea behind primary prophylaxis is to prevent negative consequences of certain behaviours (like tobacco smoking) to health and life. However, if it impossible to avoid them completely, the aim should be to limit to the highest degree the exposure to harmful factors, although lesser exposure does not equate a lesser risk to life.

An overview of numerous studies, such as those conducted by the WHO Working Group, has demonstrated that cancerogenic compounds, e.g. aldehydes and volatile organic compounds, have been reduced in HTPs by about $80 \%$ to $99 \%$, while the content of mercury decreased by ca $75 \%$ [58]. Polycyclic hydrocarbons and carbon oxide generated by incomplete incineration are also lowered in HTPs by about $90 \%$. However, it is worth remembering that the time of observation of HTP users is insufficient to draw final conclusions, and many of the relevant studies - as mentioned earlier - have been carried out by companies involved in the production of tobacco products. A good example could be two papers published in the same year, 2018, but authored by different teams of researchers. Caponnetto et al. showed that the level of carbon oxide in inhaled air did not increase due to the use of HTPs (eCO) [59]. In contrast, Adriaens et al. published their research results, also in 2018 , implicating that the use of tobacco heating systems leads to a higher concentration of eCO, although the increase is not significant clinically [60]. This arises from the fact that as tobacco is heated up to a limited temperature of $350^{\circ} \mathrm{C}, \mathrm{CO}$ can be generated by low-temperature pyrolysis [61, 62]. Moreover, it has been demonstrated that the concentration of some substances, such as propylene glycol, glycidol, acetol and 2-propen-1-ol, is higher than in the regular cigarette [63]. In 2019, the FDA issued a statement concluding that the smoke generated in the IQOS system contains other, potentially cancerogenic substances, which are unique for this type of a tobacco heating device [64].

There is a growing number of reports suggesting a beneficial effect of the shift from smoking tobacco to HTPs $[65,66]$. It is maintained that the reduced exposure to harmful factors will have a positive influence by decreasing the cancerogenic hazard. This beneficial effect might be achieved in the case of long-term smokers who cannot quit smoking. The data published by a research team from Korea show that 305 of HTP users have stopped smoking tobacco owing to this solution [67]. One of the PMI-commissioned studies showed that the use of HTPs in comparison to conventional tobacco smoking affected a reduction in the biomarkers linked to endothelial dysfunction, oxidative stress, inflammatory condition and high-density lipoproteins as well as cholesterol [2]. However, an independent study completed by Leigh et al. revealed that IQOS systems are characterised by a considerably higher cytotoxicity than e-cigarettes, although lower one than regular cigarettes [41]. St Helen et al. demonstrated that the use of IQOs diminishes the risk caused by some ( 40 out of 93 ) of the harmful substances identified by the FDA [68]. In brief, the above review shows that there are numerous studies whose results are often contradictory. 


\section{CONCLUSION}

It is doubtless that non-smoking is best for our health. However, one may consider the use of HTP systems by patients who wish to quit smoking but experience acute nicotine cravings and withdrawal symptoms. Moreover, it is possible to consider the use of these products by patients who cannot stop smoking completely, as a substitute for this addiction. Nevertheless, it remains important to continue studies on long-term effects of HTPs conducted by researchers not affiliated with tobacco companies.

\section{References}

1. Chapman S, Wakefield MA. Large-scale unassisted smoking cessation over 50 years: lessons from history for endgame planning in tobacco control. Tob Control. 2013; 22(suppl 1): i33-5. http://doi.org/10.1136/tobaccocontrol-2012-050767.

2. Ludicke F, Picavet P, Baker G et al. Effects of Switching to the Tobacco Heating System 2.2 Menthol, Smoking Abstinence, or Continued Cigarette Smoking on Biomarkers of Exposure: A Randomized, Controlled, Open-Label, Multicenter Study in Sequential Confinement and Ambulatory Settings (Part 1). Nicotine Tob Res. 2018; 20(2): 161-72. http://doi.org/10.1093/ntr/ntw287.

3. Ludicke F, Picavet P, Baker G et al. Effects of Switching to the Menthol Tobacco Heating System 2.2, Smoking Abstinence, or Continued Cigarette Smoking on Clinically Relevant Risk Markers: A Randomized, Controlled, Open-Label, Multicenter Study in Sequential Confinement and Ambulatory Settings (Part 2). Nicotine Tob Res. 2018; 20(2): 173-82. http://doi.org/10.1093/ntr/ntx028.

4. Philips Morrison International. https://www.pmi.com (access: 5.02.2021).

5. Jaccard G, Tafin Djoko D, Moennikes O et al. Comparative assessment of HPHC yields in the Tobacco Heating System THS2.2 and commercial cigarettes. Regul Toxicol Pharmacol. 2017; 90: 1-8. http://doi.org/10.1016/j.yrtph.2017.08.006.

6. Pratte P, Cosandey S, Goujon Ginglinger C. Investigation of solid particles in the mainstream aerosol of the Tobacco Heating System THS2.2 and mainstream smoke of a 3R4F reference cigarette. Hum Exp Toxicol. 2017; 36(11): 1115-20. http://doi.org/10.1177/0960327116681653.

7. Wong ET, Kogel U, Veljkovic E et al. Evaluation of the Tobacco Heating System 2.2. Part 4: 90-day OECD 413 rat inhalation study with systems toxicology endpoints demonstrates reduced exposure effects compared with cigarette smoke. Regul Toxicol Pharmacol. 2016; 81(suppl 2): S59-S81. http://doi.org/10.1016/j.yrtph.2016.10.015.

8. Schaller JP, Keller D, Poget L et al. Evaluation of the Tobacco Heating System 2.2. Part 2: Chemical composition, genotoxicity, cytotoxicity, and physical properties of the aerosol. Regul Toxicol Pharmacol. 2016; 81(suppl 2): S27-S47. http://doi.org/10.1016/j.yrtph.2016.10.001.

9. Hagemejer J, Malinowska A, Poniatowski G et al. Wpływ produkcji wyrobów tytoniowych na Polską gospodarkę. Centrum Analiz Społeczno-Rynkowych, Warszawa 2020.

10. Drope J, Schluger NW. The tobacco atlas. American cancer society; 2018.

11. Borland $\mathrm{R}$, Partos $\mathrm{TR}$, Yong $\mathrm{HH}$ et al. How much unsuccessful quitting activity is going on among adult smokers? Data from the International Tobacco Control Four Country cohort survey. Addiction. 2012; 107(3): 673-82.

12. Kaidar-Person O, Bar-Sela G, Person B. The two major epidemics of the twenty-first century: obesity and cancer. Obes Surg. 2011; 21(11): 1792-7. http://doi.org/10.1007/s11695-011-0490-2.

13. U.S. Department of Health and Human Services. The Health Consequences of Smoking - 50 Years of Progress: A Report of the Surgeon General. Department of Health and Human Services, Centers for Disease Control and Prevention, National Center for Chronic Disease Prevention and Health Promotion, Office on Smoking and Health; Atlanta, GA, USA: 2014: 1-36.

14. Secretan B, Straif K, Baan R et al. A review of human carcinogens - Part E: tobacco, areca nut, alcohol, coal smoke, and salted fish. Lancet Oncol. 2009; 10(11): 1033-4. http://doi.org/10.1016/s1470-2045(09)70326-2.

15. Agudo A, Bonet $\mathrm{C}$, Travier $\mathrm{N}$ et al. Impact of cigarette smoking on cancer risk in the European prospective investigation into cancer and nutrition study. J Clin Oncol. 2012; 30(36): 4550-7. http://doi.org/10.1200/JCO.2011.41.0183.

16. Doll R, Peto R, Boreham J et al. Mortality in relation to smoking: 50 years' observations on male British doctors. BMJ. 2004; 328(7455): 1519. http:// doi.org/10.1136/bmj.38142.554479.AE.

17. Kiiskinen U, Vartiainen E, Puska P et al. Long-term cost and life-expectancy consequences of hypertension. J Hypertens. 1998; 16(8): 1103-12. http://doi.org/10.1097/00004872-199816080-00004

18. Hay SI, Abajobir AA, Abate KH et al. Global, regional, and national disability-adjusted life-years (DALYs) for 333 diseases and injuries and healthy life expectancy (HALE) for 195 countries and territories, 1990-2016: a systematic analysis for the Global Burden of Disease Study 2016. Lancet. 2017; 390(10100): 1260-344.

19. Cheng TY, Cramb SM, Baade PD et al. The International Epidemiology of Lung Cancer: Latest Trends, Disparities, and Tumor Characteristics. J Thorac Oncol. 2016; 11(10): 1653-71. http://doi.org/10.1016/j.jtho.2016.05.021.

20. Young People Oncology Foundation Alivia and prepared by EY Poland. Access to innovative cancer drugs in Poland in comparison with selected European Union countries and Switzerland. 2015.

21. Potrykowska A, Strzelecki Z, Szymborski J et al. Zachorowalność i umieralność na nowotwory a sytuacja demograficzna Polski. Rządowa Rada Ludnościowa; 2014.

22. Didkowska J, Wojciechowska U. Zachorowania i zgony na nowotwory złośliwe w Polsce. Krajowy Rejestr Nowotworów, Centrum Onkologii - Instytut im. Marii Skłodowskiej-Curie. http://onkologia.org.pl/k/epidemiologia (access: 6.02.2021).

23. Ferlay J, Soerjomataram I, Dikshit R et al. Cancer incidence and mortality worldwide: sources, methods and major patterns in GLOBOCAN 2012. Int J Cancer. 2015; 136(5): E359-86. http://doi.org/10.1002/ijc.29210.

24. Malik K. Human development report 2013. The rise of the South: Human progress in a diverse world. The Rise of the South: Human Progress in a Diverse World (March 15, 2013) UNDP-HDRO Human Development Reports. 2013.

25. Calm J. The cancer problem. Sci Am. 1975; 233:64-78.

26. Islami F, Torre LA, Jemal A. Global trends of lung cancer mortality and smoking prevalence. Translational lung cancer research. 2015; 4(4): 327

27. Tindle HA, Stevenson Duncan M, Greevy RA et al. Lifetime Smoking History and Risk of Lung Cancer: Results From the Framingham Heart Study. J Natl Cancer Inst. 2018; 110(11): 1201-7. http://doi.org/10.1093/jnci/djy041.

28. Mallock N, Pieper E, Hutzler C et al. Heated Tobacco Products: A Review of Current Knowledge and Initial Assessments. Front Public Health. 2019; 7: 287. http://doi.org/10.3389/fpubh.2019.00287.

29. Lee A, Lee SY, Lee KS. The use of heated tobacco products is associated with asthma, allergic rhinitis, and atopic dermatitis in Korean adolescents. Scientific Reports. 2019; 9(1): 1-8.

30. Chun L, Moazed F, Matthay M et al. Possible hepatotoxicity of IQOS. Tob Control. 2018; 27(suppl 1): s39-s40. http://doi.org/10.1136/tobaccocontrol-2018-054320. 
31. Glantz S, Slade J, Bero L. Chaper 4: The search for a "safe" cigarette. University of California Press Berkeley; 1996.

32. General USPHSOotS, Prevention NCFCD, Smoking HPOo. Preventing tobacco use among youth and young adults: a report of the surgeon general. US Government Printing Office; 2012.

33. Elias J, Dutra LM, Helen GS et al. Revolution or redux? Assessing IQOS through a precursor product. Tobacco Control. 2018; 27(suppl 1): s102-s10.

34. Tobacco Tactics. Next Generation Products: British American Tobacco. https://tobaccotactics.org/wiki/next-generation-products-british-american-tobacco (access: 5.02.2021)

35. Glantz SA. Heated tobacco products: the example of IQOS. Tob Control. 2018; 27(suppl 1): s1-s6. http://doi.org/10.1136/tobaccocontrol-2018-054601.

36. Caputi TL. Industry watch: heat-not-burn tobacco products are about to reach their boiling point. Tob Control. 2016; 26(5): 609-10. http://doi. org/10.1136/tobaccocontrol-2016-053264.

37. Eaton D, Jakaj B, Forster M et al. Assessment of tobacco heating product THP1.0. Part 2: Product design, operation and thermophysical characterisation. Regul Toxicol Pharmacol. 2018; 93: 4-13. http://doi.org/10.1016/j.yrtph.2017.09.009.

38. Smith MR, Clark B, Ludicke F et al. Evaluation of the Tobacco Heating System 2.2. Part 1: Description of the system and the scientific assessment program. Regul Toxicol Pharmacol. 2016; 81(suppl 2): S17-S26. http://doi.org/10.1016/j.yrtph.2016.07.006.

39. Ludicke F, Haziza C, Weitkunat R et al. Evaluation of Biomarkers of Exposure in Smokers Switching to a Carbon-Heated Tobacco Product: A Controlled, Randomized, Open-Label 5-Day Exposure Study. Nicotine Tob Res. 2016; 18(7): 1606-13. http://doi.org/10.1093/ntr/ntw022.

40. Simonavicius E, McNeill A, Shahab L et al. Heat-not-burn tobacco products: a systematic literature review. Tob Control. 2019; 28(5): 582-94. http:// doi.org/10.1136/tobaccocontrol-2018-054419.

41. Leigh NJ, Tran PL, O'Connor RJ et al. Cytotoxic effects of heated tobacco products (HTP) on human bronchial epithelial cells. Tob Control. 2018; 27(suppl 1): s26-s9. http://doi.org/10.1136/tobaccocontrol-2018-054317.

42. Neilsen K, Glantz SA. A tobacco industry study of airline cabin air quality: dropping inconvenient findings. Tob Control. 2004; 13(suppl 1): i20-9. http://doi.org/10.1136/tc.2003.004721.

43. Wertz MS, Kyriss T, Paranjape $\mathrm{S}$ et al. The toxic effects of cigarette additives. Philip Morris' project mix reconsidered: an analysis of documents released through litigation. PLoS Med. 2011; 8(12): e1001145. http://doi.org/10.1371/journal.pmed.1001145.

44. El-Toukhy S, Baig SA, Jeong M et al. Impact of modified risk tobacco product claims on beliefs of US adults and adolescents. Tob Control. 2018, 27(suppl 1): s62-s9. http://doi.org/10.1136/tobaccocontrol-2018-054315.

45. Gentzke AS, Wang TW, Jamal A et al. Tobacco Product Use Among Middle and High School Students - United States, 2020. Morbidity and Mortality Weekly Report. 2020; 69(50): 1881.

46. Osibogun O, Taleb ZB, Bahelah R et al. Correlates of poly-tobacco use among youth and young adults: Findings from the Population Assessment of Tobacco and Health study, 2013-2014. Drug Alcohol Depend. 2018; 187: 160-4. http://doi.org/10.1016/j.drugalcdep.2018.02.024.

47. Leas EC, Cohen JE, Ayers JW. A Philip Morris advertisement for its heated tobacco product IQOS sets a troubling precedent. Tobacco Control 2020; 29(e1): e168-e70.

48. U.S. Federal Trade Commission (FTC). Cigarette Report 2018. 2018.

49. Kim M, Watkins SL, Koester KA et al. Unboxed: US Young Adult Tobacco Users'Responses to a New Heated Tobacco Product. Int J Environ Res Public Health. 2020; 17(21). http://doi.org/10.3390/ijerph17218108.

50. Churchill V, Weaver SR, Spears CA et al. IQOS debut in the USA: Philip Morris International's heated tobacco device introduced in Atlanta, Georgia. Tob Control. 2020; 29(e1): e152-e4. http://doi.org/10.1136/tobaccocontrol-2019-055488.

51. Lee CM. The Impact of Heated Tobacco Products on Smoking Cessation, Tobacco Use, and Tobacco Sales in South Korea. Korean J Fam Med. 2020; 41(5): 273-81. http://doi.org/10.4082/kjfm.20.0140.

52. Tabuchi T, Gallus S, Shinozaki T et al. Heat-not-burn tobacco product use in Japan: its prevalence, predictors and perceived symptoms from exposure to secondhand heat-not-burn tobacco aerosol. Tob Control. 2018; 27(e1): e25-e33. http://doi.org/10.1136/tobaccocontrol-2017-053947.

53. Hair EC, Bennett M, Sheen E et al. Examining perceptions about IQOS heated tobacco product: consumer studies in Japan and Switzerland. Tobacco Control. 2018; 27(suppl 1): s70-s3.

54. Dyrektywa Parlamentu Europejskiego i Rady 2014/40/UE z dnia 3 kwietnia 2014 r. w sprawie zbliżenia przepisów ustawowych, wykonawczych i administracyjnych państw członkowskich w sprawie produkcji, prezentowania i sprzedaży wyrobów tytoniowych i powiązanych wyrobów oraz uchylająca dyrektywę 2001/37/WE.

55. Morean ME, Butler ER, Bold KW et al. Preferring more e-cigarette flavors is associated with e-cigarette use frequency among adolescents but not adults. PloS ONE. 2018; 13(1): e0189015.

56. Du P, Bascom R, Fan T et al. Changes in Flavor Preference in a Cohort of Long-Term Electronic Cigarette Users. Ann Am Thorac Soc. 2020; 17(5): 573-81. http://doi.org/10.1513/AnnalsATS.201906-4720C.

57. Berg CJ. Preferred flavors and reasons for e-cigarette use and discontinued use among never, current, and former smokers. Int J Public Health 2016; 61(2): 225-36. http://doi.org/10.1007/s00038-015-0764-x.

58. Forster M, Fiebelkorn S, Yurteri C et al. Assessment of novel tobacco heating product THP1.0. Part 3: Comprehensive chemical characterisation of harmful and potentially harmful aerosol emissions. Regul Toxicol Pharmacol. 2018; 93: 14-33. http://doi.org/10.1016/j.yrtph.2017.10.006.

59. Caponnetto P, Maglia M, Prosperini G et al. Carbon monoxide levels after inhalation from new generation heated tobacco products. Respir Res. 2018; 19(1): 164. http://doi.org/10.1186/s12931-018-0867-z.

60. Adriaens K, Gucht DV, Baeyens F. IQOS(TM) vs. e-Cigarette vs. Tobacco Cigarette: A Direct Comparison of Short-Term Effects after Overnight-Abstinence. Int J Environ Res Public Health. 2018; 15(12). http://doi.org/10.3390/ijerph15122902.

61. Baker R. The formation of the oxides of carbon by the pyrolysis of tobacco. Beiträge zur Tabakforschung International/Contributions to Tobacco Research. 1975; 8(1): 16-27.

62. Herod AA, Kandiyoti R. Pyrolysis. http://www.thermopedia.com/content/1068 (access: 7.02.2021).

63. Food and Drug Administration FDA Briefing Document: January 24-25, 2018 TPSAC Meeting. 2018. https://www.fda.gov/downloads/AdvisoryCommittees/CommitteesMeetingMaterials/TobaccoProductsScientificAdvisoryCommittee/UCM593109.pdf (access: 5.02.2021).

64. Food and Drug Administration (FDA). 2019 premarket tobacco product marketing orders. 2019. https://www.fda.gov/tobacco-products/premarket-tobacco-product-applications/premarket-tobacco-product-marketing-orders (access: 7.02.2021).

65. Gale N, McEwan M, Camacho OM et al. Changes in Biomarkers of Exposure on Switching From a Conventional Cigarette to the glo Tobacco Heating Product: A Randomized, Controlled Ambulatory Study. Nicotine Tob Res. 2020. http://doi.org/10.1093/ntr/ntaa135.

66. Miura N, Yuki D, Minami N et al. A study to investigate changes in the levels of biomarkers of exposure to selected cigarette smoke constituents in Japanese adult male smokers who switched to a non-combustion inhaler type of tobacco product. Regul Toxicol Pharmacol. 2015; 71(3): 498-506. http://doi.org/10.1016/j.yrtph.2015.02.007.

67. Cho H, Kim H, Lee C et al. Analysis on use pattern of heated tobacco products and their impact on quit smoking intention. Sejong: Ministry of Health and Welfare. 2018.

68. St Helen G, Jacob lii $\mathrm{P}$, Nardone $\mathrm{N}$ et al. IQOS: examination of Philip Morris International's claim of reduced exposure. Tob Control. 2018, 27(suppl 1): s30-s6. http://doi.org/10.1136/tobaccocontrol-2018-054321. 
Authors' contributions: Anna Romaszko-Wojtowicz: 85\%; Anna Doboszyńska: 15\%.

Conflict of interests: Authors declare no conflict of interest.

Financial support:

There was no financial support.

Ethics:

The authors had full access to the data and take full responsibility for its integrity All authors have read and agreed with the content of the manuscript as written. The paper complies with the Helsinki Declaration, EU Directives and harmonized requirements for biomedical journals. https://www.journalsmededu.pl/index.php/OncoReview/index: 26.04.2023; 15:55,24 